\title{
ONCOGENES AND THE COAGULATION SYSTEM - FORCES THAT MODULATE DORMANT AND AGGRESSIVE STATES IN CANCER
}

\author{
Nathalie Magnus, Esterina D’Asti, Brian Meehan, Delphine Garnier and Janusz Rak*
}

Montreal Children's Hospital, RI MUHC, McGill University, Montreal, Quebec, Canada

*Correspondence should be sent to: Janusz Rak: Montreal Children's Hospital, Place

Toulon, 4060 Ste Catherine West, PT-232 Montreal, Quebec, H3Z 2Z3, Canada; Tel. (514) 412-4400; Fax (514) 412-4331; e-mail: janusz.rak@mcgill.ca

Running title: oncogenes, coagulation and tumor dormancy

Keywords: cancer, tissue factor, oncogenes, coagulation, dormancy, glioma, microparticles 
Abstract. Cancers arise and progress genetically amidst profound perturbations of the microenvironmental and systemic homeostasis. This includes the coagulation system, which is a part of the vascular milieu (niche) which remains under the control of molecular events occurring within the cancer cell genome. Thus, activation of several prototypic oncogenic pathways, such as RAS, EGFR, HER2, METSHH and loss of tumor suppressors (PTEN, TP53) alter the expression, activity and vesicular release of coagulation effectors, as exemplified by tissue factor (TF). The cancer-specific determinants of coagulopathy are also illustrated by the emerging link between the expression profiles of coagulation-related genes (coagulome) in glioblastoma multiforme (GBM), medulloblastoma $(\mathrm{MB})$ and possibly other cancers and molecular subtypes of these respective tumors. The state of the coagulome is consequential for growth, metastasis and angiogenesis of established tumors, but could potentially also affect dormant cancer cells. For example, $\mathrm{TF}$ expression may trigger awakening of dormant glioma cells in mice in a manner involving recruitment of vascular and inflammatory cells, and resulting in lasting changes in the cancer cell genome and epigenome. Thus, coagulation system effectors could act as both targets and (indirect) inducers of genetic tumor progression, and a better understanding of this link may hold new diagnostic and therapeutic opportunities. 


\section{Introduction.}

The haemostatic system represents the first and the most immediate element in the program of tissue responses to injury, and as such is a part of the biological continuum involving inflammation, angiogenesis, stromal cell recruitment, and repair [1-4]. It is increasingly clear that this succession represents more than just a temporal order of biological events, and instead reflects a coordinated web of mechanistically linked processes. In this regard, the emerging evidence suggests that the coagulation system activation not only precedes, but also to some extent regulates inflammation and angiogenesis [5-9]. There is also a growing appreciation for the fact that while haemostatic circuitry preserves the vascular integrity and patency, this molecular apparatus also 'informs' surrounding cells about the state of the microenvironment and about the related systemic perturbations.

Various cellular populations are molecularly equipped to receive coagulation signals, owing to their 'sensing' apparatus that consists of several receptors capable of binding the haemostatic system proteins. This includes tissue factor (TF), thrombin receptor (PAR-1) along with other protease activated receptors (PARs), urokinase receptor (uPAR), thrombomodulin (TM), endothelial protein $\mathrm{C}$ receptor (EPCR), receptors for protein $\mathrm{S}$ (TAM group), integrins, and growth factor receptors that can be transactivated by the coagulation system [10-14]. These molecular interactions activate intracellular signalling pathways and change the expression of several genes $[15,16]$, including mediators of angiogenesis, inflammation and other processes relevant to cancer $[10,17-19]$. In this manner, the various components of the haemostatic circuitry, such as factor VIIa, Xa, thrombin, fibrin, proteins $\mathrm{C}$ and $\mathrm{S}$ and others, in conjunction 
with the fibrinolytic system and platelets participate in cellular responses that extend far beyond regulation of blood liquidity.

These mechanisms are subverted in cancer in at least two important ways, namely by perpetual challenges to the vascular homeostasis posed by tumor growth, progression, angiogenesis and metastasis. An important extension of these perturbations are brought about by therapeutic interventions, including consequences of surgery, radiation, administration of chemotherapeutic and antiangiogenic agents, central venous lines and protracted immobility [20]. Collectively, these insults contribute to various forms of coagulopathy and thromboembolic disease that disproportionately affect cancer patients [21]. Indeed, thrombosis is regarded as the second leading cause of cancer related mortality [22], and a factor that independently and adversely affects therapeutic outcomes $[23,24]$.

Coagulopathy, thrombosis and Trousseau syndrome have long been regarded as unspecific consequences of cancer-related disruption in tissue anatomy and vascular continuity, or driven by vascular hyperpermeability, inflammation, stasis, toxic side effects or other factors. This perception may have influenced the way in which cancer coagulopathy is approached from a diagnostic, therapeutic and even biological point of view, that is, mainly as a generic complication and disease epiphenomenon. There are reasons to suggest, however, that activated coagulation may possess cancer-specific properties and thereby require more biologically-based diagnostic and therapeutic consideration [10,25-28]. 


\section{Oncogenic pathways and the coagulant phenotype of cancer cells}

The successes and failures of virtually all cancer treatments have their sources in underlying therapeutic and biological concepts. It is generally accepted that cancers arise as a result of mutational alterations, but it continues to be debated whether those affect a set of common core signalling pathways (and amenable to repositioning of targeted agents) [29-31], or are uniquely configured in each of the emerging types and subtypes of specific cancers (necessitating precision/personalized therapy)[32,33]. A third avenue is one that proposes that genetic events ultimately shape, and cooperate with, the tumor microenvironment (niche), which therefore needs to be a part of the therapeutic paradigm [34]. The latter applies to the coagulation system, an important facet of the vascular milieu present in all cancers.

We have initially proposed that the state of the coagulation system in cancer may be influenced by oncogenic transformation [35]. This was predicated on several considerations. Thus, if coagulation system perturbations in cancer were simply an unspecific consequence of the mass effect, tissue invasion, metastasis, therapeutic interventions, or bed rest, they would be expected to correlate with the grade, but not necessarily the type of the underlying malignancy. This is, however, not the case and cancers differ greatly with respect to the risk of venous thromboembolism (VTE). For instance, pancreatic, brain and gastrointenstinal cancers, as well as certain leukemias, are all associated with a relatively high risk of VTE, while skin, breast and prostate cancer are inherently far less prothrombotic [36-38]. This suggests that the specific phenotypes of cancer cells may affect the coagulation system, and do so in a differential manner, either directly, or through changes in the tumor microenvironment. 
The phenotypic uniqueness of cancer cells arising in different tissues rest with two major factors: the nature of the (stem) cell of origin for a particular disease, and the configuration of mutations that activate oncogenic pathways and ultimately drive the malignant process [39]. Oncogenes affect cancer cell phenotype in a manner that impacts not only their inner workings, such as mitogenesis, but also their surroundings and systemic interactions, for example with the vasculature and the bone marrow [40]. The latter aspect of the oncogenic activity may include the state of the coagulation system, an effect that could involve all three elements of the Virchov's triad (stasis, vascular wall abnormalities, and hypercoagulability).

For example, it is well known that the overabundance and deregulation of angiogenic mediators in human cancers results in formation of aberrant vascular networks characterized by a sluggish blood flow pattern [41], hyperpermeable, procoagulant [42] and incomplete endothelial lining, as well as the exposure of subendothelial tissues and tumor masses to the circulating plasma [43]. The occurrence, magnitude and nature of these effects are different in different tumor types and thereby parallel the related oncogenic drivers, their combinations and losses of tumor suppressor mechanisms. Vascular patterns may also be a function of other permanent alterations in the cancer cell genome, epigenome and chromatin architecture, all of which could contribute to reprogramming of the cellular secretome and the profile of angiogenic factors and extracellular vesicles (EVs) released by cancer cells [40,44].

These are not merely correlative findings, and it is well documented that several dominant oncogenes, such as RAS, EGFRvIII, MET, and many other genetic lesions frequently upregulate 
vascular endothelial growth factor (VEGF), the key mediator of the angiogenic circuitry [45], as well as many other proangiogenic activities [40]. Indeed, numerous, often redundant proangiogenic growth factors and angiogenesis inhibitors are regulated in this manner, along with production of extracellular matrix molecules, proteases and angiogenesis-modulating EVs harbouring a rich repertoire of bioactive mediators, as reviewed elsewhere $[40,44,46]$.

The succession of oncogenic mutations that accompanies cellular transit through pre-malignant, indolent, benign and aggressive states is often paralleled by a corresponding progression of vascular anomalies $[47,48]$. Importantly, these oncogene-driven vascular changes translate into the aforementioned aberrations in haemostatic mechanisms, processes that in highly angiogenic tumors are often associated with manifest vaso-occlusive thrombosis within the tumor microcirculation and may trigger overt or subtle coagulopathy in the periphery $[24,49,50]$. Thus, oncogenes affect the coagulation system by triggering angiogenesis.

Oncogenic pathways also influence the recruitment of inflammatory cells, which themselves may exhibit pro-angiogenic and pro-coagulant phenotypes [51,52]. For example, myeloid cells and monocytes could release TF-containing EVs (microparticles/MPs) [53], while neutrophils may deploy extracellular chromatin traps (NET-osis) [54], or participate in other events that could add to cancer-related coagulation perturbations. 
However, oncogenic pathways may also deregulate coagulation effectors more directly, through at least three different types of effects. First, certain coagulation-related genes, such as TF, which are normally expressed by various cells, either at low levels or transiently, are important regulatory targets of several oncogenic signalling pathways. This may result in abnormally high and/or constitutive expression of TF in transformed cells [8]. Second, oncogenes can trigger coagulation gene expression ectopically [55-57], that is in cancer cells originating from tissues that normally do not produce coagulation factors. Third, oncogenic and differentiation pathways may modulate biogenesis of procoagulant extracellular vesicles (EVs), including emission of TFbearing large and small (exosome-like) microparticles that could enter biofluids and general circulation [58].

In this regard oncogenic RAS may serve as an informative paradigm. Thus, mutant KRAS oncogene was initially found to upregulate the expression, activity and EV-mediated emission of TF from colorectal cancer cells. In the same cells deletion of the TP53 tumor suppressor exacerbated this procoagulant phenotype, as well as TF exposure and shedding [59]. Epidermal growth factor receptor $(E G F R)$ and the related HER-2/ErbB2 receptor tyrosine kinase (RTK) are both upstream activators of the RAS signalling cascade [60]. It is therefore not surprising that activation, amplification or mutation of EGFR (e.g. expression of ligand independent form known as EGFRvIII), as well as overexpression of HER-2 result in the increase of TF production by glioma and carcinoma cells, respectively [61] [56]. 
Several oncogenes are also known to activate hypoxia response pathways and AKT signalling [60]. Consistently with this notion the loss of PTEN tumor suppressor resulting in AKT activation was found to drive TF upregulation and procoagulant phenotype in glioma cells especially under hypoxic conditions [62-64]. TF is also upregulated by other oncogenic kinases, such as SRC [65] and MET [66]. As indicated by elegant studies on transgenic hepatoma, MET may also regulate other regulators of the coagulation system, including plasminogen activator inhibitor 1 (PAI-1) and cyclooxygenase 2 (COX-2) [67]. In pediatric brain tumor cells the expression of TF and PAR receptors are modulated by MET, sonic hedgehog (SHH) and oncogenic microRNA (miR-520g) [68].

In acute promyelocytic leukemia (APL) where profound coagulopathy is a common occurrence, the chimeric driver gene, $P M L-R A R a$, also regulates the coagulant phenotype of transformed cells, including their TF expression. This can be inferred from the effects of PML-RARa antagonists, such as all-trans retinoic acid (ATRA), which reduce the levels of TF in APL cells relieving heamostatic complications [69]. Similarly, the V617FJAK-2 mutation found in essential thrombocytemia (ET) is also linked with deregulated TF activity and perturbed coagulation [70].

Another process activated by oncogenic pathways and unique to cancer cells is the activation of ectopic expression of coagulation proteins. Thus, while under normal circumstances several components of the coagulation cascade are produced exclusively in the liver, and under control of vitamin K-regulated mechanisms [71], this requirement can be circumvented by cellular transformation. Indeed, production of coagulation factors VII and II has been reported to occur in 
hepatocyte-unrelated cancer cells $[72,73]$. This is important as vitamin $\mathrm{K}$ antagonists are often used in thromboprophylaxis, including in cancer, and it remains uncertain whether they are effective in suppressing coagulation factor production by cells harboring mutant oncogenes.

A more direct evidence for the role of oncogenes in the ectopic production of coagulation factors stems from experiments with cancer cells engineered to express a well controlled repertoire of transforming mutations [56]. For example, in a series of GBM cell lines lacking expression of PTEN (U373, U87) the enforced overexpression of the glioma-specific oncogenic EGFR mutant gene (EGFRvIII) was found to trigger a complex rearrangement of the coagulant phenotype, including the expression of FVII, TF, PAR-1, and PAR-2. Notably, these changes rendered EGFRvIII-expressing cells not only more proficient in generating FXa in coagulation assays but also responsive to exogenous FVIIa and PAR-activating peptides in terms of expression of angiogenic and inflammatory factors such as VEGF and IL-8, respectively [56]. Similar changes were also noted in medulloblastoma cells, in which oncogenic growth factors cooperated with coagulation pathway in regulation of mediators of angiogenesis and inflammation [74]. These observations suggest that activation of oncogenic pathways contributes to both quantitative and qualitative rearrangements of the cellular coagulome and these changes may have consequences for clotting and beyond [75].

\section{Molecular subtypes of cancer and changes in tumor coagulome.}

Genetic regulation of coagulation factors in cancer cells implies that molecularly distinct subtypes of human tumors should exhibit correspondingly different coagulomes. The recent 
availability of rich molecular databases collected by the The Cancer Genome Atlas (TCGA) and other profiling initiatives $[32,76,77]$ makes it possible to examine this question in silico.

Indeed, molecular profiling efforts have revolutionized the very classification and definition of malignancy. For example, in spite of similar histology, location and clinical features of human glioblastoma (GBM) exists as at least four distinct molecular subgroups (proneural, neural, classical, and mesenchymal), a notion that is highly consequential for future targeted therapies, whether directed at the tumor or at the host cell compartments $[32,78,79]$. GBM subgroups effectively constitute different disease entities, which can be distinguished by profiles of mutational events, methylation patterns and gene expression. These features include, and are a function of, the underlying oncogenic pathways [78].

It was of considerable interest to find that molecular diversity of GBM, indeed, translates into subtype-specific features of coagulomes analysed at the mRNA level in a large cohort of tumor specimens. For example, the elevated TF and PAR-1 mRNA expression correlated strongly with the classical GBM subtype, in which upregulation and amplification of EGFR is among the most predominant characteristics [57]. This is consistent with the aforementioned in vitro observations, which suggested that EGFR and EGFRvIII regulate TF and PAR-1 in cultured glioma cells, both at the protein and mRNA level [56]. In contrast, in proneural GBM the expression of both TF and EGFR mRNA was relatively low, but these tumors characterized by a strong presence of stem cell markers (SOX-2) appear to express increased levels of FVII mRNA. Also in mesenchymal GBM, TF levels are lower than in the classical subtype, but, instead, these 
tumors express high levels of PAI-1, uPA, uPAR, EPCR, thrombomodulin among other changes [57]. While the levels of corresponding proteins and their activities are presently unknown, it should be noted that, as expected, the levels of TF protein are non-uniformly distributed among human GBM samples, at least according to testing performed thus far (Magnus, Meehan and Rak - unpublished observation). These observations are thought provoking, as all GBMs are considered highly procoagulant, and are thought to exhibit features of intravascular thrombosis and high risk of VTE $[24,49]$. Whether such risk is a function of GBM subtype is presently unknown. Regardless whether this is found to be the case, it may be possible that in different patients, thrombosis could be triggered by somewhat different mechanisms and could, hypothetically, be opposed using approaches based on the coagulome of the underlying disease.

Pediatric brain tumors are usually not considered to be a source of clinically relevant thromboembolic disease [80], and therefore the role of coagulation pathway in this setting is infrequently studied [74]. It could be argued, however, that this may represent an oversight, as biological effects of the coagulation system and their oncogenic drivers in these tumors may still be relevant. In this regard, medulloblastoma (MB) represents the most common form of aggressive brain malignancies in children. MBs are associated with embryonal characteristics, and originate from the neuronal cell lineage, mostly within the cerebellum [81]. Importantly, in spite of limited histological diversity these tumors vary widely with respect to the age of onset, aggressiveness, and especially responses to therapy and prognosis [82]. Once again, in recent years the traditional description of MB has been challenged by molecular classification that distinguishes at least four molecular subgroups of the disease (WNT, SHH, Group 3, and Group 4) with vastly different clinical properties [77]. 
To assess whether MB subgroups entail differences in the ability of cancer cells to engage vascular system we compared their profiles of angiogenic, inflammatory and coagulation factors using the existing databases and by profiling cultured MB cells [68]. This analysis revealed marked differences in gene expression and enforced the link between oncogenic growth factor pathways and the cancer cell coagulome. For example, TF mRNA expression was preferentially elevated only in the SHH subgroup of $\mathrm{MB}$, and this coincided with higher levels the protooncogenic MET receptor in these tumors. Interestingly, MB-derived cells co-stimulated with SHH and hepatocyte growth factor (MET agonist) exhibited a similar TF upregulation, along with altered responsiveness to thrombin and a series of unique changes in the profile of angiogenic and inflammatory factors [74]. In view of these observations, it could be argued that even in cancers not associated with clinically apparent thrombosis (like MB), coagulation system may be engaged in a consequential manner [50]. Moreover, not only the extent, but also the mechanistic nature of this interaction could be influenced by unique oncogenic circuitries that define types, subtypes and potentially individual cases of human cancers [57,74]. The implications of these relationships remain presently unexplored.

\section{Coagulation system as modulator of tumor initiation, progression and dormancy}

Arguably the coagulant phenotype of cancer cells could be viewed as one of several important effector mechanisms that link genetic progression of the disease and its biological, as well as clinical appearances in patients. This does not necessarily imply a direct proportionality between procoagulant properties and cellular, or clinical aggressiveness [83]. Rather, this is meant to suggest that deregulation of haemostatic proteins may influence the tumor microenvironment in 
several pathogenetically significant ways and that many but not all of these changes are procoagulant.

Evidence to this effect includes the role of clotting factors and platelets in such fundamental processes in cancer as cellular growth, angiogenesis, metastasis, inflammation, therapeutic responsiveness and vascular comorbidities, as extensively reviewed in the recent literature [6,7,20,21,25,84-91]. Notably, pharmacological and genetic strategies targeting TF, FVIIa, thrombin, platelets and other coagulation mechanisms led to anti-tumor and anti-metastatic effects [61,92-96], which are often comparable to other 'main stream' targeted agents [87,93]. Moreover, anticoagulation with low molecular weight heparin (LMWH) was in several clinical studies associated with a detectable (albeit limited) survival advantage in certain cancer settings [20,97-102].

One of the less studied, but tantalizing, questions is whether coagulation system plays a role at pre-clinical, or otherwise occult stages of malignancy, such as events surrounding tumor initiation by cancer stem cells (CSCs), post-therapeutic repopulation, or tumor dormancy $[61,103]$. In this regard, Karpatkin first postulated that thrombin may trigger growth of dormant cancer cells [104], a notion of considerable importance given microscopic prevalence of ostensibly transformed cells in the adult and elderly population [105]. Contact with soft fibrin has also been proposed as a milieu that may enrich for CSCs [106]. 
It could be speculated that dormant cells could be awaken by tissue injury or repair responses such as clotting and inflammation. In this regard it is intriguing that injuries such as head trauma were reported to increase the risk for brain tumor formation later in life [107]. Similarly, higher frequency of colorectal cancer was recently described in certain (albeit not all) forms of thrombophilia, especially in association with the homozygous mutation of the Factor V Leiden [108]. Of note in this context are well controlled and elegantly executed studies of Palumbo and colleagues who demonstrated that in a mouse model were colon cancer originates on the background of inflammatory bowel disease, coagulation factors, such as fibrinogen are an essential part of the disease pathogenesis. In this setting the leukocyte binding domain of fibrinogen (Fiby390-396A) was required for tumor formation, a finding that suggests a link between coagulation and inflammation [109]. This is also important because in this model cancer cells are not introduced externally, but are formed endogenously in mice subjected to the proinflammatory protocol of azoxymethane and dextran sodium sulfate exposure, and thereby the related processes likely induce (transform) colonic epithelium to form a full blown adenoma $[25,109]$. It remains unclear whether the nexus of inflammatory and coagulant events is mainly a part of the supportive niche for CSCs transformed by another mechanism (mutagenesis), or whether host responses are responsible for the transformation process.

During the long natural history of adult human cancers these possibilities do not have to be mutually exclusive. As mentioned earlier, several human tissues contain morphologically transformed but dormant cells, and such cells can also be found in the bone marrow of patients in remission after clinically effective anticancer treatment [105,110-112]. Exit from such a 
quiescent state represents an important and potentially targetable event in the onset and progression of the malignant disease [110].

In this regard, we observed that certain human glioma cell lines exhibit a remarkable (permanent) dormant phenotype in mice. These cells also express extremely low levels of TF and negligible procoagulant activity. These properties dramatically change upon expression of the oncogenic EGFRvIII in these cells, a change that renders them TF-positive, procoagulant and highly aggressive [56]. Notably, introduction of similar levels of TF by transfection, but in the absence of EGFRvIII-dependent transformation, also interrupted the dormant state of indolent glioma, but did so in a delayed and less aggressive manner. In this case, TF-expressing glioma cells entered into a transitory latent state, after which tumors emerged in the majority, but not all, of injected mice, and no earlier that within 2-4 months post injection.

Interestingly, within 1-3 weeks after inoculation of control and TF-transfected glioma cells their surrounding microenvironment in vivo underwent a profound histological rearrangement. Thus, the injection sites containing TF-high cells (but not those inoculated with TF-low control counterparts) became infiltrated with blood vessels and inflammatory cells, especially CD11b+ myeloid cells and F4/80+ macrophages. This occurred months before the tumor onset could be observed clinically and by bioluminescent imaging, and suggested that host cells could act as triggers and mediators of the TF-dependent exit of indolent cancer cells from their dormant state [113]. 
In order to determine whether this delayed tumor onset represents a stable phenotype of these cells, tissues were recovered re-established in culture and re-injected into secondary recipients. Surprisingly, in this case TF-high tumors emerged rapidly, indicating a stable change in the cellular phenotype that occurred in vivo in addition to the initial TF expression. This was underscored by differences in the gene expression profile between TF transfected cells and their tumor-derived isogenic counterparts (PT cells). Strikingly, the latter cells also exhibited permanent changes in their genome and epigenome that were, clearly, not a function of TF expression but arose within the TF-dependent procoagulant and inflammatory microenvironment. Thus, PT cells exhibited gene copy number variations, as indicated by SNP analysis, and had a profoundly altered DNA methylation profile.

These observations suggest that while TF may have a role in regulating cellular properties due to signalling responses its effects may also be more lasting. For example, in the aforementioned indolent glioma model TF-dependent changes in the tissue microenvironment, including angiogenesis and inflammation resulted in genetic and epigenetic evolution of tumor cells beyond the expression of procoagulant phenotype. The exact mechanisms, generality and the impact of the procoagulant milieu on the cancer cell genome and epigenome remain to be more thoroughly investigated [113].

\section{Summary}

Among many scenarios leading to development of human cancers cycles of microenvironmental and genetic changes are increasingly noticeable. Indeed, driver mutations are mostly acquired 
and enriched for, through interactions of mutant (stem) cells with their surroundings. There are reasons to believe that the coagulation system is, at least in some cases, an important part of these perturbations. Haemostatic mechanisms are aberrantly activated by cancer cells harboring oncogenic mutations, and in a manner dependent on molecular subtypes of the underlying malignancy.

At the same time coagulation system is a part of the vascular milieu that may facilitate, often indirectly, the initiation of malignant process by pre-existing cancer cells or awakening of dormant tumors. It is also possible, as discussed earlier, that the coagulation pathway may contribute to a chain of events that change the genetic and epigenetic hardwiring of cancer cells, possibly resulting in oncogenic mutations. Thus, TF and coagulation effectors may play different roles not only in different cancers but also at different stages in cancer progression and in different biological settings.

These considerations raise several questions. Should clinical studies involving anticoagulants in cancer include stratification according to molecular subtype of the disease, and in view of the respective coagulomes? Is there a role for conventional, new [114], or 'next generation (targeted)' anticoagulation in the prevention and management of human cancers (which ones), possibly beyond thromboprophylaxis? Are coagulant events relevant occurring at older age relevant to age-related cancer incidence? If so does this involve awakening of dormant cells? Do coagulation perturbations act on such cells systemically (through emission of exosomes)? 
Generalizations are tempting, but a rigorous scrutiny and careful analysis of the specific disease contexts is where some of the answers may lay.

\section{Acknowledgements.}

This work was supported by operating grants to JR Canadian Institutes of Health Research (CIHR; MOP 102736). NM and EDA are recipients of the doctoral studentships from Fonds de recherche en santé du Québec (FRSQ), which also provided infrastructure support. JR is the Jack Cole Chair in Pediatric Hematology/Oncology at McGill University. DG is a former recipient of Thelma Adams Postdoctoral Award from the Foundation of Stars/CHF. We are indebted to our families and colleagues for their support and feedback.

Conflict of Interest. Authors declare no conflict of interest. 


\section{References}

1. Dvorak HF. Tumors: wounds that do not heal. $N$ Engl J Med 1986; 315: 1650-1659.

2. Browder T, Folkman J, Pirie-Shepherd S. The haemostatic system as a regulator of angiogenesis. J Biol Chem 2000; 275: 1521-1524.

3. Dahlback B. Coagulation and inflammation--close allies in health and disease. Semin Immunopathol 2012; 34: 1-3.

4. van Hinsbergh V. Endothelium--role in regulation of coagulation and inflammation. Semin Immunopathol 2012; 34: 93-106.

5. Mueller BM, Reisfeld RA, Edgington TS, Ruf W. Expression of tissue factor by melanoma cells promotes efficient hematogenous metastasis. Proc Natl Acad Sci U S A 1992; 89: 11832-11836.

6. Ruf W. Tissue factor and cancer. Thromb Res 2012; 130 Suppl 1:S84-7. doi: 10.1016/j.thromres.2012.08.285.: S84-S87.

7. Kasthuri RS, Taubman MB, Mackman N. Role of tissue factor in cancer. J Clin Oncol 2009; 27: 4834-4838.

8. Rickles FR. Cancer and thrombosis in women - molecular mechanisms. Thromb Res 2009; 123 Suppl 2:S16-20.: S16-S20.

9. Engelmann B, Massberg S. Thrombosis as an intravascular effector of innate immunity. Nat Rev Immunol 2013; 13: 34-45.

10. Ruf W, Disse J, Carneiro-Lobo TC, Yokota N, Schaffner F. Tissue factor and cell signalling in cancer progression and thrombosis. $J$ Thromb Haemost 2011; 9 Suppl 1:306-15. doi: 10.1111/j.1538-7836.2011.04318.x.: 306-315.

11. Esmon CT. Structure and functions of the endothelial cell protein C receptor. Crit Care Med 2004; 32: S298-S301.

12. Mackman N. Triggers, targets and treatments for thrombosis. Nature 2008; 451: 914-918.

13. Wiiger MT, Prydz H. The epidermal growth factor receptor (EGFR) and proline rich tyrosine kinase 2 (PYK2) are involved in tissue factor dependent factor VIIa signalling in HaCaT cells. Thromb Haemost 2004; 92: 13-22.

14. Lemke G. Biology of the TAM Receptors. Cold Spring Harb Perspect Biol 2013; 5: a009076.

15. Camerer E, Gjernes E, Wiiger M, Pringle S, Prydz H. Binding of factor VIIa to tissue factor on keratinocytes induces gene expression. J Biol Chem 2000; 275: 6580-6585. 
16. Albrektsen T, Sorensen BB, Hjorto GM, Fleckner J, Rao LV, Petersen LC.

Transcriptional program induced by factor VIIa-tissue factor, PAR1 and PAR2 in MDAMB-231 cells. J Thromb Haemost 2007; 5: 1588-1597.

17. Abe K, Shoji M, Chen J, Bierhaus A, Danave I, Micko C, Casper K, Dillehay DL, Nawroth PP, Rickles FR. Regulation of vascular endothelial growth factor production and angiogenesis by the cytoplasmic tail of tissue factor. Proc Natl Acad Sci U S A 1999; 96: $8663-8668$.

18. Bromberg ME, Sundaram R, Homer RJ, Garen A, Konigsberg WH. Role of tissue factor in metastasis: functions of the cytoplasmic and extracellular domains of the molecule. Thromb Haemost 1999; 82: 88-92.

19. McEachron TA, Pawlinski R, Richards KL, Church FC, Mackman N. Protease-activated receptors mediate crosstalk between coagulation and fibrinolysis. Blood 2010; 116: 50375044.

20. Falanga A, Marchetti M, Vignoli A. Coagulation and cancer: biological and clinical aspects. J Thromb Haemost 2013; 11: 223-233.

21. Rickles FR. Mechanisms of cancer-induced thrombosis in cancer. Pathophysiol Haemost Thromb 2006; 35: 103-110.

22. Khorana AA, Francis CW, Culakova E, Kuderer NM, Lyman GH. Thromboembolism is a leading cause of death in cancer patients receiving outpatient chemotherapy. $J$ Thromb Haemost 2007; 5: 632-634.

23. Sorensen HT, Mellemkjaer L, Olsen JH, Baron JA. Prognosis of cancers associated with venous thromboembolism. $N$ Engl J Med 2000; 343: 1846-1850.

24. Perry JR. Thromboembolic disease in patients with high-grade glioma. Neuro Oncol 2012; 14 Suppl 4:iv73-iv80. doi: 10.1093/neuonc/nos197.: iv73-iv80.

25. Degen JL, Palumbo JS. Haemostatic factors, innate immunity and malignancy. Thromb Res 2012; 129 Suppl 1:S1-5. doi: 10.1016/S0049-3848: -3.

26. Geddings JE, Mackman N. Tumor-derived tissue factor-positive microparticles and venous thrombosis in cancer patients. Blood 2013; 122: 1873-1880.

27. Elice F, Rodeghiero F, Falanga A, Rickles FR. Thrombosis associated with angiogenesis inhibitors. Best Pract Res Clin Haematol 2009; 22: 115-128.

28. Rak J, Milsom C, Yu J. Tissue factor in cancer. Curr Opin Hematol 2008; 15: 522-528.

29. Beroukhim R, Mermel CH, Porter D, Wei G, Raychaudhuri S, Donovan J, Barretina J, Boehm JS, Dobson J, Urashima M, Mc Henry KT, Pinchback RM, Ligon AH, Cho YJ, Haery L, Greulich H, Reich M, Winckler W, Lawrence MS, Weir BA, Tanaka KE, Chiang DY, Bass AJ, Loo A, Hoffman C, Prensner J, Liefeld T, Gao Q, Yecies D, 
Signoretti S, Maher E, Kaye FJ, Sasaki H, Tepper JE, Fletcher JA, Tabernero J, Baselga J, Tsao MS, Demichelis F, Rubin MA, Janne PA, Daly MJ, Nucera C, Levine RL, Ebert BL, Gabriel S, Rustgi AK, Antonescu CR, Ladanyi M, Letai A, Garraway LA, Loda M, Beer DG, True LD, Okamoto A, Pomeroy SL, Singer S, Golub TR, Lander ES, Getz G, Sellers WR, Meyerson M. The landscape of somatic copy-number alteration across human cancers. Nature 2010; 463: 899-905.

30. Hwang TH, Atluri G, Kuang R, Kumar V, Starr T, Silverstein KA, Haverty PM, Zhang Z, Liu J. Large-scale integrative network-based analysis identifies common pathways disrupted by copy number alterations across cancers. BMC Genomics 2013; 14:440. doi: 10.1186/1471-2164-14-440.: 440-14.

31. Omberg L, Ellrott K, Yuan Y, Kandoth C, Wong C, Kellen MR, Friend SH, Stuart J, Liang H, Margolin AA. Enabling transparent and collaborative computational analysis of 12 tumor types within The Cancer Genome Atlas. Nat Genet 2013; 45: 1121-1126.

32. Verhaak RG, Hoadley KA, Purdom E, Wang V, Qi Y, Wilkerson MD, Miller CR, Ding L, Golub T, Mesirov JP, Alexe G, Lawrence M, O'Kelly M, Tamayo P, Weir BA, Gabriel S, Winckler W, Gupta S, Jakkula L, Feiler HS, Hodgson JG, James CD, Sarkaria JN, Brennan C, Kahn A, Spellman PT, Wilson RK, Speed TP, Gray JW, Meyerson M, Getz G, Perou CM, Hayes DN. Integrated genomic analysis identifies clinically relevant subtypes of glioblastoma characterized by abnormalities in PDGFRA, IDH1, EGFR, and NF1. Cancer Cell 2010; \%19;17: 98-110.

33. Flaherty KT, Hodi FS, Fisher DE. From genes to drugs: targeted strategies for melanoma. Nat Rev Cancer 2012; 12: 349-361.

34. Folkman J. Angiogenesis: an organizing principle for drug discovery? Nat Rev Drug Discov 2007; 6: 273-286.

35. Rak J, Klement G. Impact of oncogenes and tumor suppressor genes on deregulation of hemostasis and angiogenesis in cancer. Cancer Metastasis Rev 2000; 19: 93-96.

36. Alcalay A, Wun T, Khatri V, Chew HK, Harvey D, Zhou H, White RH. Venous thromboembolism in patients with colorectal cancer: incidence and effect on survival. $J$ Clin Oncol 2006; 24: 1112-1118.

37. Wun T, White RH. Epidemiology of cancer-related venous thromboembolism. Best Pract Res Clin Haematol 2009; 22: 9-23.

38. Stein PD, Beemath A, Meyers FA, Skaf E, Sanchez J, Olson RE. Incidence of venous thromboembolism in patients hospitalized with cancer. Am J Med 2006; 119: 60-68.

39. Vogelstein B, Papadopoulos N, Velculescu VE, Zhou S, Diaz LA, Jr., Kinzler KW. Cancer genome landscapes. Science 2013; 339: 1546-1558.

40. Rak J. Ras oncogenes and tumor vascular interface. In: A.Thomas-Tikhonenko (editor). Cancer Genome and Tumor Microenvironment. New York: Springer, 2009; 133-165. 
41. Jain RK, di TE, Duda DG, Loeffler JS, Sorensen AG, Batchelor TT. Angiogenesis in brain tumors. Nat Rev Neurosci 2007; 8: 610-622.

42. Contrino J, Hair G, Kreutzer DL, Rickles FR. In situ detection of tissue factor in vascular endothelial cells: correlation with the malignant phenotype of human breast disease. Nat Med 1996; 2: 209-215.

43. Dvorak FH, Rickles FR. Malignancy and Hemostasis. In: Coleman RB, Marder VJ, Clowes AW, George JN, Goldhaber SZ (editors). Hemostasis and Thrombosis: Basic Principles and Clinical Practice. Philadelphia: Lippincott Company Williams \& Wilkins, 2006; 851-873.

44. Al-Nedawi K, Meehan B, Rak J. Microvesicles: messengers and mediators of tumor progression. Cell Cycle 2009; 8: 2014-2018.

45. Rak J, Mitsuhashi Y, Bayko L, Filmus J, Sasazuki T, Kerbel RS. Mutant ras oncogenes upregulate VEGF/VPF expression: implications for induction and inhibition of tumor angiogenesis. Cancer Res 1995; 55: 4575-4580.

46. Bouck N, Stellmach V, Hsu SC. How tumors become angiogenic. Adv Cancer Res 1996; 69: $135-174$.

47. Relf M, LeJeune S, Scott PA, Fox S, Smith K, Leek R, Moghaddam A, Whitehouse R, Bicknell R, Harris AL. Expression of the angiogenic factors vascular endothelial cell growth factor, acidic and basic fibroblast growth factor, tumor growth factor beta-1, platelet-derived endothelial cell growth factor, placenta growth factor, and pleiotrophin in human primary breast cancer and its relation to angiogenesis. Cancer Res 1997; 57: 963 969.

48. Rak J, Filmus J, Kerbel RS. Reciprocal paracrine interactions between tumor cells and endothelial cells. The "angiogenesis progression" hypothesis. Eur J Cancer 1996; 32A: 2438-2450.

49. Brat DJ, Van Meir EG. Vaso-occlusive and prothrombotic mechanisms associated with tumor hypoxia, necrosis, and accelerated growth in glioblastoma. Lab Invest 2004; 84: 397-405.

50. Buccoliero AM, Castiglione F, Rossi DD, Franchi A, Paglierani M, Sanzo M, Cetica V, Giunti L, Sardi I, Genitori L, Taddei GL. Embryonal tumor with abundant neuropil and true rosettes: morphological, immunohistochemical, ultrastructural and molecular study of a case showing features of medulloepithelioma and areas of mesenchymal and epithelial differentiation. Neuropathology 2010; 30: 84-91.

51. Sparmann A, Bar-Sagi D. Ras-induced interleukin-8 expression plays a critical role in tumor growth and angiogenesis. Cancer Cell 2004; 6: 447-458.

52. Phan VT, Wu X, Cheng JH, Sheng RX, Chung AS, Zhuang G, Tran C, Song Q, Kowanetz M, Sambrone A, Tan M, Meng YG, Jackson EL, Peale FV, Junttila MR, 
Ferrara N. Oncogenic RAS pathway activation promotes resistance to anti-VEGF therapy through G-CSF-induced neutrophil recruitment. Proc Natl Acad Sci U S A 2013; 110: 6079-6084.

53. Del Conde I, Shrimpton CN, Thiagarajan P, Lopez JA. Tissue-factor-bearing microvesicles arise from lipid rafts and fuse with activated platelets to initiate coagulation. Blood 2005; 106: 1604-1611.

54. Demers M, Krause DS, Schatzberg D, Martinod K, Voorhees JR, Fuchs TA, Scadden DT, Wagner DD. Cancers predispose neutrophils to release extracellular DNA traps that contribute to cancer-associated thrombosis. Proc Natl Acad Sci U S A 2012; 109: 1307613081.

55. Koizume S, Yokota N, Miyagi E, Hirahara F, Nakamura y, Sakuma Y, Yoshida A, Kameda Y, Tsuchiya E, Ruf W, Miyagi Y. Hepatocyte nuclear factor-4-independent synthesis of coagulation factor VII in breast cancer cells and its inhibition by targeting selective histone acetyltransferases. Mol Cancer Res 2009; 7: 1928-1936.

56. Magnus N, Garnier D, Rak J. Oncogenic epidermal growth factor receptor up-regulates multiple elements of the tissue factor signaling pathway in human glioma cells. Blood 2010; 116: 815-818.

57. Magnus N, Gerges N, Jabado N, Rak J. Coagulation-related gene expression profile in glioblastoma is defined by molecular disease subtype. Journal of Thrombosis and Haemostasis 2013; 11: 1197-1200.

58. Garnier D, Magnus N, Lee TH, Bentley V, Meehan B, Milsom C, Montermini L, Kislinger T, Rak J. Cancer Cells Induced to Express Mesenchymal Phenotype Release Exosome-like Extracellular Vesicles Carrying Tissue Factor. J Biol Chem 2012; 287: 43565-43572.

59. Yu JL, May L, Lhotak V, Shahrzad S, Shirasawa S, Weitz JI, Coomber BL, Mackman N, Rak JW. Oncogenic events regulate tissue factor expression in colorectal cancer cells: implications for tumor progression and angiogenesis. Blood 2005; 105: 1734-1741.

60. Avraham R, Yarden Y. Feedback regulation of EGFR signalling: decision making by early and delayed loops. Nat Rev Mol Cell Biol 2011; 12: 104-117.

61. Milsom CC, Yu JL, Mackman N, Micallef J, Anderson GM, Guha A, Rak JW. Tissue factor regulation by epidermal growth factor receptor and epithelial-to-mesenchymal transitions: effect on tumor initiation and angiogenesis. Cancer Res 2008; 68: 1006810076.

62. Rong Y, Post DE, Pieper RO, Durden DL, Van Meir EG, Brat DJ. PTEN and hypoxia regulate tissue factor expression and plasma coagulation by glioblastoma. Cancer Res 2005; 65: 1406-1413. 
63. Rong Y, Hu F, Huang R, Mackman N, Horowitz JM, Jensen RL, Durden DL, Van Meir EG, Brat DJ. Early growth response gene-1 regulates hypoxia-induced expression of tissue factor in glioblastoma multiforme through hypoxia-inducible factor-1-independent mechanisms. Cancer Res 2006; 66: 7067-7074.

64. Rong Y, Belozerov VE, Tucker-Burden C, Chen G, Durden DL, Olson JJ, Van Meir EG, Mackman N, Brat DJ. Epidermal growth factor receptor and PTEN modulate tissue factor expression in glioblastoma through JunD/activator protein-1 transcriptional activity. Cancer Res 2009; 69: 2540-2549.

65. Jahner D, Hunter T. The stimulation of quiescent rat fibroblasts by v-src and v-fps oncogenic protein-tyrosine kinases leads to the induction of a subset of immediate early genes. Oncogene 1991; 6: 1259-1268.

66. Provencal M, Berger-Thibault N, Labbe D, Veitch R, Boivin D, Rivard GE, Gingras D, Beliveau R. Tissue factor mediates the HGF/Met-induced anti-apoptotic pathway in DAOY medulloblastoma cells. J Neurooncol 2010; 97: 365-372.

67. Boccaccio C, Sabatino G, Medico E, Girolami F, Follenzi A, Reato G, Sottile A, Naldini L, Comoglio PM. The MET oncogene drives a genetic programme linking cancer to haemostasis. Nature 2005; 434: 396-400.

68. D'Asti, E., Huang, A., and Rak, J. Downregulation of tissue factor (TF) in medulloblastoma cells expressing miR-520g . Proceedings Keystone Syposia, Snowmass, CO, March 30, 2012. 2012.

69. Tallman MS, Lefebvre P, Baine RM, Shoji M, Cohen I, Green D, Kwaan HC, Paietta E, Rickles FR. Effects of all-trans retinoic acid or chemotherapy on the molecular regulation of systemic blood coagulation and fibrinolysis in patients with acute promyelocytic leukemia. J Thromb Haemost 2004; 2: 1341-1350.

70. Falanga A, Marchetti M, Vignoli A, Balducci D, Russo L, Guerini V, Barbui T. V617F JAK-2 mutation in patients with essential thrombocythemia: relation to platelet, granulocyte, and plasma haemostatic and inflammatory molecules. Exp Hematol 2007; 35: 702-711.

71. Colman RW, Marder VJ, Clowes AW. Overview of Coagulation, Fibrynolysis, and their Regulation. In: Coleman RB, Marder VJ, Clowes AW, George JN, Goldhaber SZ (editors). Hemostasis and Thrombosis: Basic Principles and Clinical Practice. Philadelphia: Lippincott Company Williams \& Wilkins, 2006; 17-20.

72. Koizume S, Jin MS, Miyagi E, Hirahara F, Nakamura y, Piao JH, Asai A, Yoshida A, Tsuchiya E, Ruf W, Miyagi Y. Activation of cancer cell migration and invasion by ectopic synthesis of coagulation factor VII. Cancer Res 2006; 66: 9453-9460.

73. Schulze EB, Hedley BD, Goodale D, Postenka CO, Al-Katib W, Tuck AB, Chambers AF, Allan AL. The thrombin inhibitor Argatroban reduces breast cancer malignancy and 
metastasis via osteopontin-dependent and osteopontin-independent mechanisms. Breast Cancer Res Treat 2008; 112: 243-254.

74. D'Asti E, Kool M, Korshunov A, Huang A, Pfister S, Rak J. Molecular subtypes define the composition of coagulome in medulloblastoma. Manuscript in preparation 2013.

75. Rak J, Yu JL, Luyendyk J, Mackman N. Oncogenes, trousseau syndrome, and cancerrelated changes in the coagulome of mice and humans. Cancer Res 2006; 66: 1064310646.

76. Parsons DW, Jones S, Zhang X, Lin JC, Leary RJ, Angenendt P, Mankoo P, Carter H, Siu IM, Gallia GL, Olivi A, McLendon R, Rasheed BA, Keir S, Nikolskaya T, Nikolsky Y, Busam DA, Tekleab H, Diaz LA, Jr., Hartigan J, Smith DR, Strausberg RL, Marie SK, Shinjo SM, Yan H, Riggins GJ, Bigner DD, Karchin R, Papadopoulos N, Parmigiani G, Vogelstein B, Velculescu VE, Kinzler KW. An integrated genomic analysis of human glioblastoma multiforme. Science 2008; 321: 1807-1812.

77. Kool M, Korshunov A, Remke M, Jones DT, Schlanstein M, Northcott PA, Cho YJ, Koster J, Schouten-van MA, van VD, Clifford SC, Pietsch T, von Bueren AO, Rutkowski S, McCabe M, Collins VP, Backlund ML, Haberler C, Bourdeaut F, Delattre O, Doz F, Ellison DW, Gilbertson RJ, Pomeroy SL, Taylor MD, Lichter P, Pfister SM. Molecular subgroups of medulloblastoma: an international meta-analysis of transcriptome, genetic aberrations, and clinical data of WNT, SHH, Group 3, and Group 4 medulloblastomas. Acta Neuropathol 2012; 123: 473-484.

78. Ohgaki H, Kleihues P. Genetic profile of astrocytic and oligodendroglial gliomas. Brain Tumor Pathol 2011; 28: 177-183.

79. Sturm D, Witt H, Hovestadt V, Khuong-Quang DA, Jones DT, Konermann C, Pfaff E, Tonjes M, Sill M, Bender S, Kool M, Zapatka M, Becker N, Zucknick M, Hielscher T, Liu XY, Fontebasso AM, Ryzhova M, Albrecht S, Jacob K, Wolter M, Ebinger M, Schuhmann MU, Van MT, Fruhwald MC, Hauch H, Pekrun A, Radlwimmer B, Niehues T, von KG, Durken M, Kulozik AE, Madden J, Donson A, Foreman NK, Drissi R, Fouladi M, Scheurlen W, von DA, Monoranu C, Roggendorf W, Herold-Mende C, Unterberg A, Kramm CM, Felsberg J, Hartmann C, Wiestler B, Wick W, Milde T, Witt O, Lindroth AM, Schwartzentruber J, Faury D, Fleming A, Zakrzewska M, Liberski PP, Zakrzewski K, Hauser P, Garami M, Klekner A, Bognar L, Morrissy S, Cavalli F, Taylor MD, van SP, Koster J, Versteeg R, Volckmann R, Mikkelsen T, Aldape K, Reifenberger G, Collins VP, Majewski J, Korshunov A, Lichter P, Plass C, Jabado N, Pfister SM. Hotspot mutations in H3F3A and IDH1 define distinct epigenetic and biological subgroups of glioblastoma. Cancer Cell 2012; 22: 425-437.

80. Athale U, Siciliano S, Thabane L, Pai N, Cox S, Lathia A, Khan A, Armstrong A, Chan AK. Epidemiology and clinical risk factors predisposing to thromboembolism in children with cancer. Pediatr Blood Cancer 2008; 51: 792-797.

81. Gilbertson RJ, Ellison DW. The origins of medulloblastoma subtypes. Annu Rev Pathol 2008; 3:341-65.: 341-365. 
82. Northcott PA, Korshunov A, Pfister SM, Taylor MD. The clinical implications of medulloblastoma subgroups. Nat Rev Neurol 2012; 8: 340-351.

83. Thaler J, Ay C, Mackman N, Bertina RM, Kaider A, Marosi C, Key NS, Barcel DA, Scheithauer W, Kornek G, Zielinski C, Pabinger I. Microparticle-associated tissue factor activity, venous thromboembolism and mortality in pancreatic, gastric, colorectal and brain cancer patients. J Thromb Haemost 2012; 10: 1363-1370.

84. Nash GF. Tissue factor (TF) and vascular endothelial growth factor (VEGF) expression in colorectal cancer: relation with cancer recurrence. Colorectal Dis 2007; 9: 858-859.

85. Young A, Chapman O, Connor C, Poole C, Rose P, Kakkar AK. Thrombosis and cancer. Nat Rev Clin Oncol 2012; 9: 437-449.

86. Buller HR, van Doormaal FF, van Sluis GL, Kamphuisen PW. Cancer and thrombosis: from molecular mechanisms to clinical presentations. J Thromb Haemost 2007; 5 Suppl 1: $246-254$.

87. Versteeg HH, Schaffner F, Kerver M, Petersen HH, Ahamed J, Felding-Habermann B, Takada Y, Mueller BM, Ruf W. Inhibition of tissue factor signaling suppresses tumor growth. Blood 2008; 111: 190-199.

88. Keshava S, Kothari H, Rao LV, Pendurthi UR. Influence of endothelial cell protein C receptor on breast cancer development. J Thromb Haemost 2013; 10.

89. Amirkhosravi A, Meyer T, Amaya M, Davila M, Mousa SA, Robson T, Francis JL. The role of tissue factor pathway inhibitor in tumor growth and metastasis. Semin Thromb Hemost 2007; 33: 643-652.

90. Auer RA, Scheer AS, McSparron JI, Schulman AR, Tuorto S, Doucette S, Gonsalves J, Fong Y. Postoperative venous thromboembolism predicts survival in cancer patients. Ann Surg 2012; 255: 963-970.

91. Gil-Bernabe AM, Ferjancic S, Tlalka M, Zhao L, Allen PD, Im JH, Watson K, Hill SA, Amirkhosravi A, Francis JL, Pollard JW, Ruf W, Muschel RJ. Recruitment of monocytes/macrophages by tissue factor-mediated coagulation is essential for metastatic cell survival and premetastatic niche establishment in mice. Blood 2012; 119: 3164-3175.

92. Zacharski LR. Malignancy as a solid-phase coagulopathy: implications for the etiology, pathogenesis, and treatment of cancer. Semin Thromb Hemost 2003; 29: 239-246.

93. Palumbo JS, Talmage KE, Massari JV, La Jeunesse CM, Flick MJ, Kombrinck KW, Hu Z, Barney KA, Degen JL. Tumor cell-associated tissue factor and circulating haemostatic factors cooperate to increase metastatic potential through natural killer cell-dependent and-independent mechanisms. Blood 2007; 110: 133-141.

94. Ngo CV, Picha K, McCabe F, Millar H, Tawadros R, Tam SH, Nakada MT, Anderson GM. CNTO 859, a humanized anti-tissue factor monoclonal antibody, is a potent 
inhibitor of breast cancer metastasis and tumor growth in xenograft models. Int $J$ Cancer 2007; 120: 1261-1267.

95. Liu Y, Jiang P, Capkova K, Xue D, Ye L, Sinha SC, Mackman N, Janda KD, Liu C. Tissue factor-activated coagulation cascade in the tumor microenvironment is critical for tumor progression and an effective target for therapy. Cancer Res 2011; 71: 6492-6502.

96. Zhao J, Aguilar G, Palencia S, Newton E, Abo A. rNAPc2 inhibits colorectal cancer in mice through tissue factor. Clin Cancer Res 2009; 15: 208-216.

97. Kakkar AK, Levine MN, Kadziola Z, Lemoine NR, Low V, Patel HK, Rustin G, Thomas M, Quigley M, Williamson RC. Low molecular weight heparin, therapy with dalteparin, and survival in advanced cancer: the fragmin advanced malignancy outcome study (FAMOUS). J Clin Oncol 2004; 22: 1944-1948.

98. Lee AY, Rickles FR, Julian JA, Gent M, Baker RI, Bowden C, Kakkar AK, Prins M, Levine MN. Randomized comparison of low molecular weight heparin and coumarin derivatives on the survival of patients with cancer and venous thromboembolism. J Clin Oncol 2005; 23: 2123-2129.

99. Altinbas M, Coskun HS, Er O, Ozkan M, Eser B, Unal A, Cetin M, Soyuer S. A randomized clinical trial of combination chemotherapy with and without low-molecularweight heparin in small cell lung cancer. J Thromb Haemost 2004; 2: 1266-1271.

100. Klerk CP, Smorenburg SM, Otten HM, Lensing AW, Prins MH, Piovella F, Prandoni P, Bos MM, Richel DJ, van Tienhoven G, Buller HR. The effect of low molecular weight heparin on survival in patients with advanced malignancy. J Clin Oncol 2005; 23: 21302135.

101. Akl EA, Gunukula S, Barba M, Yosuico VE, van Doormaal FF, Kuipers S, Middeldorp S, Dickinson HO, Bryant A, Schunemann H. Parenteral anticoagulation in patients with cancer who have no therapeutic or prophylactic indication for anticoagulation. Cochrane Database Syst Rev 2011; CD006652.

102. Zhang J, Zhang YL, Ma KX, Qu JM. Efficacy and safety of adjunctive anticoagulation in patients with lung cancer without indication for anticoagulants: a systematic review and meta-analysis. Thorax 2013; 68: 442-450.

103. Milsom C, Anderson GM, Weitz JI, Rak J. Elevated tissue factor procoagulant activity in CD133-positive cancer cells. J Thromb Haemost 2007; 5: 2550-2552.

104. Karpatkin S. Does hypercoagulability awaken dormant tumor cells in the host? J Thromb Haemost 2004; 2: 2103-2106.

105. Black WC, Welch HG. Advances in diagnostic imaging and overestimations of disease prevalence and the benefits of therapy. N Engl J Med 1993; 328: 1237-1243. 
106. Liu J, Tan Y, Zhang H, Zhang Y, Xu P, Chen J, Poh YC, Tang K, Wang N, Huang B. Soft fibrin gels promote selection and growth of tumorigenic cells. Nat Mater 2012; 11: 734-741.

107. Hochberg F, Toniolo P, Cole P. Head trauma and seizures as risk factors of glioblastoma. Neurology 1984; 34: 1511-1514.

108. Vossen CY, Hoffmeister M, Chang-Claude JC, Rosendaal FR, Brenner H. Clotting factor gene polymorphisms and colorectal cancer risk. J Clin Oncol 2011; 29: 1722-1727.

109. Steinbrecher KA, Horowitz NA, Blevins EA, Barney KA, Shaw MA, Harmel-Laws E, Finkelman FD, Flick MJ, Pinkerton MD, Talmage KE, Kombrinck KW, Witte DP, Palumbo JS. Colitis-associated cancer is dependent on the interplay between the haemostatic and inflammatory systems and supported by integrin alpha(M)beta(2) engagement of fibrinogen. Cancer Res 2010; 70: 2634-2643.

110. Goss PE, Chambers AF. Does tumor dormancy offer a therapeutic target? Nat Rev Cancer 2010; 10: 871-877.

111. Aguirre-Ghiso JA. Models, mechanisms and clinical evidence for cancer dormancy. Nat Rev Cancer 2007; 7: 834-846.

112. Uhr JW, Pantel K. Controversies in clinical cancer dormancy. Proc Natl Acad Sci U S A 2011; 108: 12396-12400.

113. Magnus N, Garnier D, Meehan B, Hashemi M, Lee T-H, Milsom CC, Jabado N, Pawlinski R, Mackman N, Rak J. Procoagulant receptor tissue factor provokes the escape from brain tumor dormancy. Proc Am Assoc Cancer Res 2013.

114. Weitz JI. Potential of new anticoagulants in patients with cancer. Thromb Res 2010; 125 Suppl 2:S30-5.: S30-S35. 


\section{Figure Legends}

\section{Figure 1. Coagulome in glioblastoma multiforme is influenced by molecular subtypes.}

Coagulation-related genes are expressed in brain tumor tissues as revealed by searching the available databases. While some of these changes represent quantitative increase in coagulant effectors, such as TF, in other cases coagulation related genes are expressed ectopically, as is the case for FVII (see text, adapted from Magnus et al 2013; see text).

Figure 2. A model linking differential pathways of genetic cancer progression with variability of the coagulant phenotype. We propose that as in the case of GBM the source of deeper molecular diversity in human cancers stems from the variability of cells of origin and their transforming genomic events. The resulting formation of molecular subtypes of disease, often with similar morphology, may translate into correspondingly different interfaces with the host vascular system, and diversity in coagulation profiles. The procoagulant milieu of certain human cancers could impact genetic and phenotypic properties of cancer cells (see text).

Figure 3. Exit of cancer cells from dormancy - the possible interplay between cancer cell genome and coagulant microenvironment. Indolent or dormant phenotype of cells lacking tumor initiating capacity may be altered in the presence of 'wound healing microenvironment', including angiogenesis, inflammation and procoagulant activity. Cancer cells exposed chronically to these factors may acquire permanent changes in their phenotype, epigenome and genome. In turn, oncogenic genomic events alter interactions of cancer cells with the coagulation system (see text). 
Coagulomes in molecular subtypes of human glioblastoma

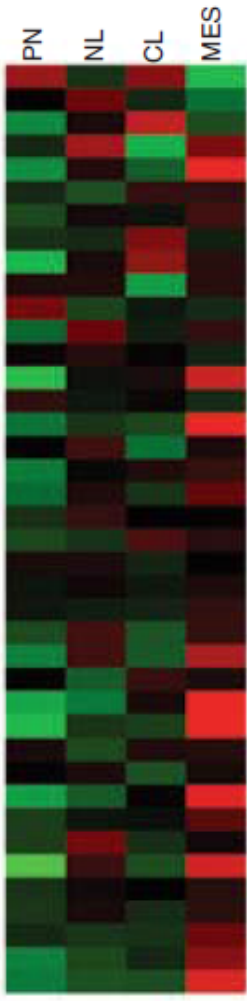

SOX2-SRY (sex determining region Y)-box 2

GABRA1-gamma-aminobutyric acid (GABA) A receptor alpha 1

EGFR-epidermal growth factor receptor

TLR4-toll-like receptor 4

TLR2-toll-like receptor 2

EGR1-early growth response 1

F2-coagulation factor II (thrombin)

F2R-coagulation factor Il (thrombin) receptor

F3-coagulation factor III (tissue factor)

F5-coagulation factor $\mathrm{V}$ (proaccelerin

F7-coagulation factor VII'(serum prothrombin conversion accelerator)

F8-coagulation factor VIII procoagulant component

F11-coagulation factor $\mathrm{XI}$

F11R-F11 receptor

F12-coagulation factor XII (Hageman factor)

F13A1-coagulation factor XIII A1 polypeptide

F13B-coagulation factor XIII B polypeptide

F2RL1-coagulation factor II (thrombin) receptor-like

F2RL2-coagulation factor II (thrombin) receptor-like 2

F2RL3-coaqulation factor II (thrombin) receptor-like 3

VWF-von Willebrand factor

FGA-fibrinogen alpha chain

FGB-fibrinogen beta chain

FGG-fibrinogen gamma chain

FGL1-fibrinogen-like 1

FGL2-fibrinogen-like 2

PLAT-plasminogen activator tissue

PLAU-plasminogen activator urokinase

PLAUR-plasminogen activator urokinase receptor

SERBP1-SERPINE1 mRNA binding protein 1

SERPINB2-plasminogen activator inhibitor type 2

SERPINE1-plasminogen activator inhibitor type 1

SERPINF2-serpin peptidase inhibitor clade $F$ member 2

THPO-thrombopoietin

PROCR-protein C receptor endothelial

SERPINC1-serpin peptidase inhibitor clade $C$ (antithrombin) member 1

SERPIND1-serpin peptidase inhibitor clade D (heparin cofactor) member 1

TFPI-tissue factor pathway inhibitor

TFPI2-tissue factor pathway inhibitor 2

THBD-thrombomodulin
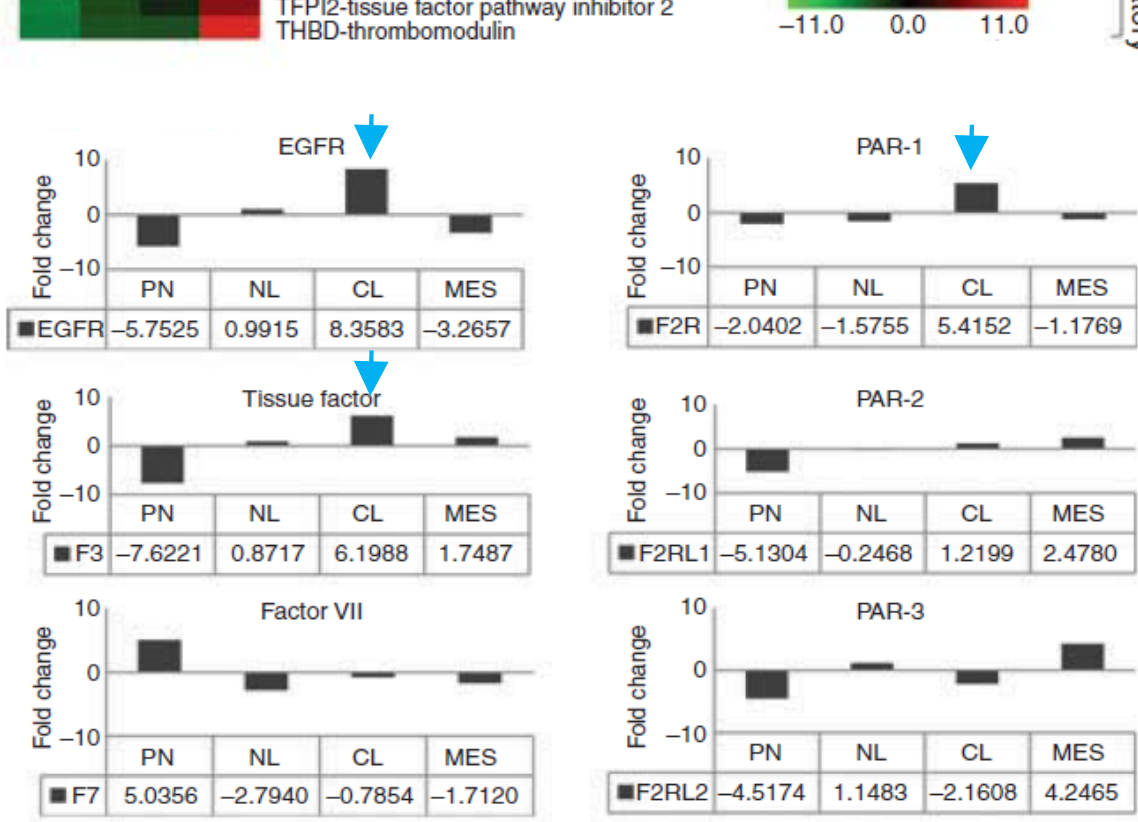

PN - Proneural GBM

$\mathrm{NL}$ - Neural GBM

$\mathrm{CL}$ - Classical GBM

MES - Mesenchymal GBM

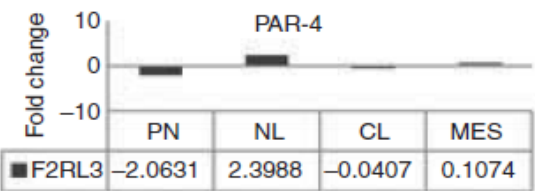

Figure 1. Magnus et al 
Interrelationship between genetic tumor progression and cancer coagulome

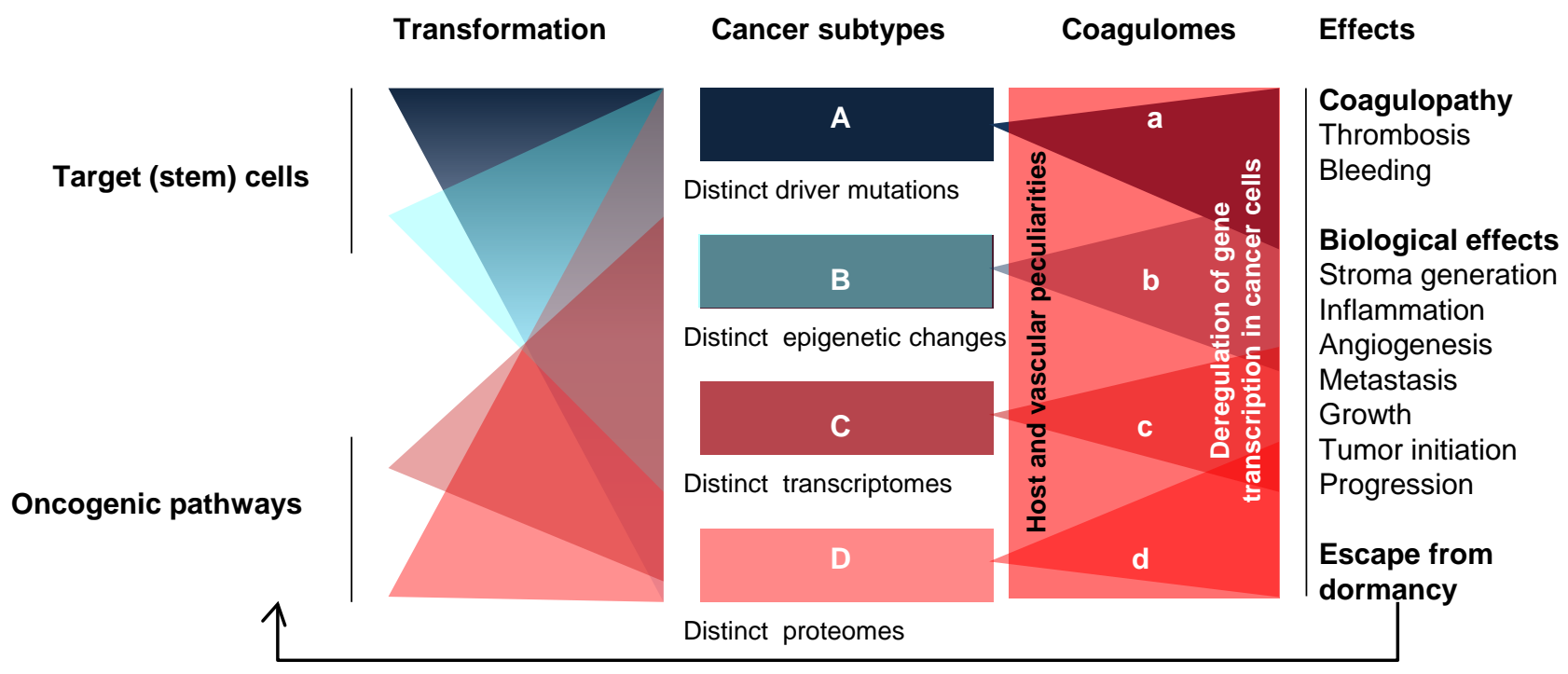

Figure 2. Magnus et al 
Exit of cancer cells from dormancy - a hypothesis

reciprocal interplay between cancer cell genome and coagulant microenvironment

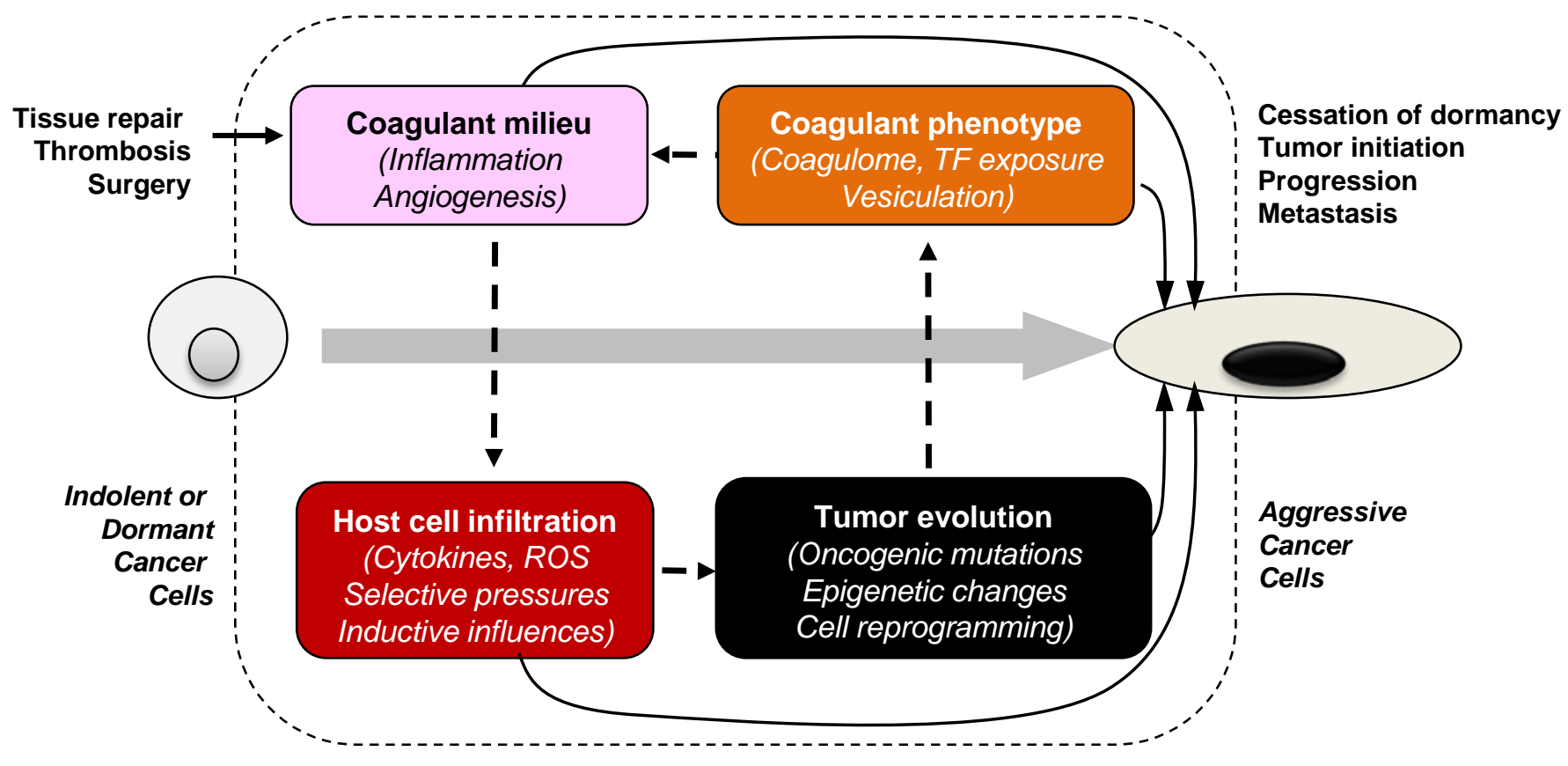

